\title{
EDITORIAL
}

\section{Inimitable Imatinib: the range of targeted tumours expands to include T-cell lymphoma}

Leukemia (2013) 27, 759; doi:10.1038/leu.2012.304

Anaplastic large cell lymphoma, anaplastic lymphoma kinase + $(\mathrm{ALCL}, \mathrm{ALK}+)$, has a relatively good prognosis but also a high rate of relapse and while these patients often remain chemosensitive, they still suffer the side effects of conventional chemotherapy. ${ }^{1}$ New targeted agents are slowly entering the clinical arena but it may take some time for these to filter through, specifically to the paediatric population. In contrast, the Abl, c-kit and plateletderived growth factor receptor (PDGFR) inhibitor Imatinib has long since been used in the clinic in the treatment of chronic myeloid leukaemia (CML). ${ }^{2}$ However, Imatinib was previously dismissed as a treatment for ALCL, ALK + as ALK is not a target of this drug. ${ }^{3}$

This October in Nature Medicine Lukas Kenner and colleagues demonstrate the efficacy of Imatinib in the treatment of ALCL. ${ }^{4}$ In this case, unlike CML, the target is the PDGFR expressed to high levels on the tumour cells. Not only do they demonstrate efficacy in a mouse model but also present data pertaining to compassionate use of Imatinib in the treatment of a 27-year-old patient who remains in complete remission. The patient in question had failed to respond to conventional therapy and had relapsed following autologous stem cell transplantation. However, following just 10 days of $400 \mathrm{mg}$ per day of Imatinib, the patient entered complete clinical remission and remains so 19 months later.

The authors also showed that PDGFR is expressed on a large majority of ALK + ALCL cases, on a sizable fraction of ALK - ALCL cases and to some extent on other T-cell lymphomas, including angioimmunoblastic T-cell lymphoma (AITL) and peripheral T-cell lymphoma, not otherwise specified (PTCL, NOS), indicating it may be of therapeutic use in other lymphoma sub-types. Indeed, compassionate use of Imatinib in the treatment of three further lymphoma sufferers that were positive for PDGFR expression has been performed; one patient diagnosed with AITL and a further two with PTCL, NOS (personal communication; a synopsis of the results is shown in Table 1). These responses may at first glance seem minimal but considering the poor state in which the patients presented and the prior course of the disease, the extended lifespan demonstrates potential efficacy that most likely will be considerable if used as a first-line agent likely in combination with conventional agents. Indeed, Lukas Kenner and colleagues demonstrated that at least in a murine model of $A L C L$, Imatinib works synergistically with the ALK inhibitor Crizotinib.

The exact mechanism of Imatinib in T-cell lymphoma remains to be determined but what is clear is that it holds much promise in the future therapy of these patients. It has been demonstrated that in cases of paediatric $A L C L$, patients can be stratified according to minimal disseminated disease and immunity to the ALK antigen. ${ }^{5}$ In future clinical trials, it may also be worth analysing patients for the presence of PDGFR on tumour cells. Whether PDGFR expression will align with patient prognosis and susceptibility to Imatinib remains to be seen but it could well present an alternative treatment strategy in the near future.

\section{ACKNOWLEDGEMENTS}

We would like to thank to Professor Stefano A Pileri, Pier Paolo Piccaluga, Pier Luigi Zinzani and Lukas Kenner for sharing their unpublished patient data.

SD Turner, on behalf of the European Research Initiative on ALCL Division of Molecular Histopathology, Department of Pathology, University of Cambridge, Cambridge, UK Email: sdt36@cam.ac.uk

\section{REFERENCES}

1 Ferreri AJ, Govi S, Pileri SA, Savage KJ. Anaplastic large cell lymphoma, ALK-positive. Crit Rev Oncol Hematol 2012; 83: 293-302.

2 Shami PJ, Deininger M. Evolving treatment strategies for patients newly diagnosed with chronic myeloid leukemia: the role of second-generation BCR-ABL inhibitors as first-line therapy. Leukemia 2012; 26: 214-224.

3 Gunby RH, Ahmed S, Sottocornola R, Gasser M, Redaelli S, Mologni L et al. Structural insights into the ATP binding pocket of the anaplastic lymphoma kinase by site-directed mutagenesis, inhibitor binding analysis, and homology modeling. $J$ Med Chem 2006; 49: 5759-5768.

4 Laimer D, Dolznig H, Kollmann K, Vesely PW, Schlederer M, Merkel O et al. Identification of PDGFR blockade as a rational and highly effective therapy for NPM-ALK driven lymphomas. Nature Medicine 2012; e-pub ahead of print 14 October 2012; doi:10.1038/nm.2966.

5 Mussolin L, Damm-Welk C, Pillon M, Zimmermann M, Franceschetto G, Pulford K et al. Use of minimal disseminated disease and immunity to NPM-ALK antigen to stratify ALK-positive ALCL patients with different prognosis. Leukemia 2012; e-pub ahead of print 21 August 2012; doi:10.1038/leu.2012.205.

\begin{tabular}{|c|c|c|c|c|c|c|c|c|}
\hline Diagnosis & $\begin{array}{l}\text { Age at } \\
\text { diagnosis }\end{array}$ & $\begin{array}{c}\text { Stage at } \\
\text { presentation }\end{array}$ & $\begin{array}{l}\text { First-line } \\
\text { treatment }\end{array}$ & $\begin{array}{c}\text { Time to first } \\
\text { relapse } \\
\text { (months) }\end{array}$ & $\begin{array}{l}\text { Number of } \\
\text { relapses }\end{array}$ & Salvage therapy & $A S C T$ & $\begin{array}{l}\text { Duration of } \\
\text { stable response } \\
\text { to Imatinib } \\
\text { (months) }\end{array}$ \\
\hline AITL & 56 & IIIB & CHOP-21 26 & 3 & 3 & $\begin{array}{l}\text { DAHP } \times 2 \text { (first relapse), } \\
\text { IGEV } \times 2 \text { (second relapse) } \\
\text { Imatinib (third relapse) }\end{array}$ & Yes & 1 \\
\hline PTCL, NOS patient. no. 1 & 51 & IIIB & MACOP-B $\times 12$ & 6 & 2 & $\begin{array}{l}\text { IEV } \times 2 \text { Imatinib (send } \\
\text { relapse) }\end{array}$ & Yes & 1 \\
\hline PTCL, NOS patient. no. 2 & 55 & IIA & MACOP-B $\times 12$ & 4 & 1 & Imatinib & No & 7 \\
\hline
\end{tabular}

Abbreviations: AITL, angioimmunoblastic T-cell lymphoma; ASCT, autologous stem cell transplantation; PTCL, NOS, peripheral T-cell lymphoma, not otherwise specified. 